\title{
PENINGKATAN KEMAMPUAN MEMAHAMI TEKS BIOGRAFI MELALUI METODE THE LEARNING CELL PADA KELAS VIIID SMP NEGERI 6 WONOMULYO KABUPATEN POLEWALI MANDAR
}

\begin{abstract}
Abdul Azis*
ABSTRACT

This research is based on the problem of the low ability of students to understand biographical texts. The cause of the low ability of students to understand the text is because the learning methods used are still conventional, the implementation of which still takes place in one direction (monotonous), the students are less involved in the learning process, students are only waiting for what is delivered by the teacher. This study aims to describe the ability to understand biographical texts through the Learning Cell method in class VIIID students of Wonomulyo 6th Middle School. The subjects of this study were eighth grade students of SMP Negeri 6 Wonomulyo, Bulo District, Polewali Mandar Regency, 2016-2017 academic year, totaling 27 students. Data collection techniques carried out in this study were Test, Observation and Documentation. The results of the study on students of SMP Negeri 6 Wonomulyo, experienced an increase in this was proven by looking at the results of the research analyzed showed that in the first cycle the average value was 2.40 and experienced an increase in the second cycle with an average value of 3.15. So the use of The Learning Cell method in understanding biographical texts can improve student learning outcomes. In addition, observational data in each cycle showed a change in the attitude of students towards a more positive, both from the attitude of learning, activeness in reading and writing notes, as well as discipline in doing the assignments given.
\end{abstract}

Keywords: Biographical text, learning cell method

*) Prodi Pendidikan Bahasa Indonesia, Universitas Al Asyariah Mandar, E-mail: azis.sumanna@gmail.com 


\section{PENDAHULUAN}

Pendidikan memiliki makna yang sangat penting dalam kehidupan manusia, karena melalui pendidikanlah manusia akan lebih mudah untuk melestarikan hidupnya dan dengan melalui pendidikan manusia akan mendapatkan pengalaman dan pengetahuan yang luas agar dapat menjadi generasi penerus bangsa.

Kurikulum adalah semua pengalaman yang telah direncanakan untuk mempersiapkan peserta didik untuk mencapai tujuan pendidikan. Tujuan perencanaan kurikulum dikembangkan dalam bentuk kerangka teori dan penelitian terhadap kekuatan sosial, pengembangan masyarakat, kebutuhan gaya belajar peserta didik (Rusman, 2009:21).

Adapun kurikulum yang diterapkan di SMP Negeri 6 Wonomulyo yaitu kurikulum 2013. Kurikulum 2013 sering juga disebut dengan kurikulum ber basis karakter. Kurikulum ini merupakan kurikulum baru yang dikeluarkan oleh kementrian pendidikan dan kebudayaan republik Indonesia. Kurikulum 2013 merupakan sebuah kurikulum yang mengutamakan pada pemahaman, skill, dan pendidikan berkarakter dimana siswa dituntut untuk paham atas materi, aktif dalam proses berdiskusi dan presentasi serta memiliki sopan santun dan sikap disiplin yang tinggi.

Sebelum peserta didik dapat memahami teks Biografi, terlebih dahulu peserta didik membaca teks biografi tersebut. Salah satu aspek keterampilan berbahasa yang paling sering memperoleh penekanan di sekolah adalah keterampilan yang materinya banyak membahas tentang wacana kewacanaan atau teks yang terdapat dalam buku. Membaca merupakan salah satu cara untuk memperoleh pengetahuan, kepandaian, atau ilmu keterampilan yang menguntungkan dalam studi. Dalam rangka kegiatan membaca diperlukan adanya teknik membaca secara efektif dan efesien agar mudah memahami apa arti makna yang terdapat dalam teks biografi tersebut.

Biografi merupakan sebuah buku yang menceritakan kejadiankejadian hidup seseorang. Lewat biografi tersebut dapat ditemukan hubungan keterangan arti dari sebuah misteri yng melindungi hidup seseorang dan juga merupkan penjelasan mengenai tindakan atau perilaku dalam hidupnya. Dalam kamus besar bahasa Indonesia, biografi berarti 
riwayat hidup seseorang yang ditulis oleh orang lain. Sebuah biografi lebih kompleks dari pada sekedar daftar tanggal lahir atau tanggal mati dan data pekerjaan seseorang. Dalam biografi dijelaskan secara lengkap kehidupan tokoh sejak kecil hingga tua. Bahkan hingga tutup usia. Semua jasa karya dan segala aspek yang dilakukan atau dihasilkan seorang tokoh. (Zabadi dan Sutejo, 2014:39).Dalam biografi tokoh banyak hal yang dapat diperoleh oleh siswa seperti keteladanan tokoh, perjuangan tokoh, hingga karakter tokoh yang dapat dikembangkan siswa dalam kegiatan sehari-hari (Sugiarti, 2014:2).

Berdasarkan observasi yang dilakukan sebelumya serta informasi yang telah didapatkan dari guru bahasa Indonesia di sekolah tersebut, permasalahan yang dialami peserta didik tersebut dalam hal pembelajaran bahasa indonesia khususnya masalah yang di alami oleh peserta didik kelas VIII D SMP Negeri 6 Wonomulyo yaitu peserta didik masih kurang pemahamannya terhadap materi yang diajarkan oleh gurunya, dan juga masih kurang penggunaan bahasa yang sesuai dengan konteks resmi oleh peserta didik, sehingga hasil belajar peserta didik tidak mampu mencapai nilai KKM yaitu 2,67. Berdasarkan permasalahan yang ada dalam pembelajaran Bahasa Indonesia di sekolah, perlu di rumuskan suatu metode pembelajaran yang baik guna meningkatkan pemahaman peserta didik dalam belajar. Metode pembelajaran yang diasumsikan yaitu metode Learning Cell dalam pembelajaran memahami teks biografi. Bahwa peserta didik dituntut untuk berpasangan dan saling bertanya jawab berdasarkan materi teks biografi.Learning Cell merupakan proses belajar dalam bentuk berpasangan, dimana peserta didik bertanya dan menjawab pertanyaan secara bergantian berdasarkan materi bacaan yang sama (Suprijono, 2009:143)

Peneltian dengan menggunakan materi teks biografi pernah diteliti oleh Rosriani dengan judul "Kemampuan membaca intensif biografi tokoh peserta didik kelas VIII SMP Negeri 2 Kecamatan Tappalang Barat". Adapun yang dibahas didalam yaitu bagaimana cara peserta didik agar dapat memahami biografi tokoh dalam buku teks yaitu dengan cara peserta didik harus lebih banyak membaca teks biografi tokoh karna dengan membaca tentunya peserta didik juga lebih bisa memahami isi teks tersebut. 
Berdasarkan latar belakang yang dibahas sebelumnya, peneliti tertarik mengadakan penelitian dengan mengambil judul "Peningkatan kemampuan memahami teks biografi melalui metode The Learning Cell pada peserta didik kelas VIII D SMP Negeri 6 Wonomulyo kecamatan Bulo kabupaten Polewali Mandar".

Adapun masalah dalam peneltian ini adalah "Bagaimanakah peningkatan kemampuan memahami teks biografi melalui metode The learning Cell pada peserta didik kelas VIII D SMP Negeri 6 Wonomulyo dan tujuan yang ingin dicapai dalam penelitian ini yaitu untuk mengetahui peningkatan kemampuan memahami teks biografi melalui metode The Learning Cell peserta didik kelas VIII D SMP Negeri 6 Wonomulyo.

Membaca merupakan satu aspek dari keterampilan berbahasa. Dalam komunikasi tulisan, lambang-lambang bunyi bahasa diubah menjadi lambang tulisan atau huruf. Pembagian membaca berdasarkan tingkatan dapat dibedakan menjadi dua yaitu, membaca permulaan dan pemahaman membaca (reading comprehension). Membaca permulaan terdapat proses pengubahan yang harus dibina dan dikuasai terutama dilakukan pada masa kanak-kanak. Pada masa permulaan sekolah, anakanak diberikan pengenalan huruf sebagai lambang bunyi bahasa. Pengenalan huruf tersebut dinamakan proses pengubahan, setelah tahap pengubahan tersebut dikuasai peserta didik secara mantap, barulah penekanan diberikan pada pemahaman isi bacaan (Alek dan Ahmad, 2010:74).

Teks biografi berasal dari bahasa yunani yang berarti bios yang memiliki arti hidup dan garaphien yang berarti tulis. Biorafi merupakan sebuah tulisan yang membahas tentang kehidupan seseorang. Secara sederhana biografi dapat diartikan sebagai kisah riwayat hidup seseorang. Biografi sendiri dapat berbentuk hanya beberapa baris kalimat saja, namun bisa melebihi dari satu buku. Biografi singkat hanya menjelaskan tentang fakta-fakta dari kehidupan seseorang serta peran pentingnya. (Zahabdi dan Sutejo, 2014:39)

Langkah langkah dalam pembelajaran the learning cellyaitu pertama Sebagai persiapan, peserta didik diberi tugas membaca suatu bacaan kemudian menulis pertanyaan yang berhubungan dengan masalah 
pokok yang muncul dari bacaan atau materi terkait lainnya. Pada awal pertemuan, peserta didik ditunjuk untuk berpasangan dengan mencari kawan yang disenangi. Peserta didik A memulai dengan membacakan pertanyaan pertama dan dijawab oleh peserta didik B.Setelah mendapatkan jawaban dan mungkin telah dilakukan koreksi atau diberi tambahan informasi, giliran peserta didik B mengajukan pertanyaan yang harus dijawab oleh peserta didik A, Jika peserta didik A selesai mengajukan satu pertanyaan, kemudian dijawab oleh peserta didik B, ganti B yang bertanya, dan begitu seterusnya, Selama berlangsung Tanya jawab, guru bergerak dari satu pasangan ke pasangan yang lain sambil memberi masukan atau penjelasan dengan bertanya atau menjawab pertanyaan(Suprijono,2009:143)

Proses pembelajaran kelompok dengan menggunakan Dari teknik pembelajaran the learning cell memilik kelebihan yang lebih menonjolkan proses pembelajaran dilakukan oleh siswa sendiri baik sesudah pembelajaran atau pada proses pembelajaran itu sendiri, memacu siswa belajar sepanjang waktu dan pembelajaran tidak dilaksanakan hanya pada saat jadwal pembelajaran tetapi sesudah dan sebelum pembelajaranpun siswa dituntut untuk mendapat mendapat informasi tentang materi pelajaran dan kelemahan dari proses pembelajaran seperti diatas dapat diantisipasi oleh guru dengan beberapa cara sehingga the learning cell ini tetap sesuai dengan rencana. Guru dituntut kreatif dalam menumbuhkan kemauan siswa dalam memperolah informasi tentang materi pelajaran terutama sesudah dan sebelum materi diajarkan.

\section{METODE PENELITIAN}

Jenis pada penelitian adalah Penilitian Tindakan Kelas atau PTK (Classroom Action). Memiliki peran yang sangat penting dan strategi untuk meningkatkan mutu pembelajaran apabila diimplementasikan dengan baik dan benar. Penelitian tindakan kelas merupakan terjemahan dari class room resech yaitu sutu penelitian tindakan yang dilakukan di kelas. yang meliputi empat tahap yang dirumuskan oleh Kunandar, (2012: 423) yaitu Planning (rencana), Action (tindakan), Observation (pengamatan) dan Reflection (refleksi). 
Adapun yang menjadi subjek dari penelitian ini adalah peserta didik kelas VIII D SMP Negeri 6 Wonomulyo yang penelitiannya dilakukan 4 pertemuan persiklus yaitu siklus I dan siklus II.Penelitian ini menggunakan dua instrumen penelitian, yakni instrumen tes dan nontes. Instrumen tes yang digunakan dalam penelitian ini untuk mengetahui kemampuan memahami teks biografi peserta didik. Instrumen nontes yang dalam penelitian ini adalah teknik observasi dan dokumentasi.

Dalam menyelesaikan penelitian ini, teknik pengumpulan data yang digunakan yaitu teknik tes dan nontes. Analisis data penelitian ini, penulis menggunakan teknik analisis data kualitatif dan analisis data kuantitatif. Data kualitatif adalah data yang berbentuk kata-kata, misalnya wawancara, dokumentasi, serta hasil observasi di lapangan. Analisis data kuantitatif adalah analisis data yang berupa angka-angka. Tujuan dari analisis ini adalah untuk memahami apa yang terdapat dibalik dan meringkasnya menjadi rumusan yang mudah untuk dimengerti.

\section{HASIL DAN PEMBAHASAN}

Tabel 1. Distribusi Frekuensi dan Presentase Hasil tes siklus I

\begin{tabular}{|c|c|c|c|c|c|}
\hline $\begin{array}{c}\text { N } \\
\text { o }\end{array}$ & Interval kelas & Konversi & Kategori & Frekuensi & $\begin{array}{c}\text { Persentas } \\
\text { e }\end{array}$ \\
\hline 1 & $90 \%-100 \%$ & $3,66 \%-4,00 \%$ & Sangat Mampu & - & \\
2 & $72 \%-89 \%$ & $2,66 \%-3,65 \%$ & Mampu & 9 & $33,33 \%$ \\
3 & $57 \%-71 \%$ & $1,66 \%-2,65 \%$ & Cukup Mampu & 15 & $55,55 \%$ \\
4 & $34 \%-56 \%$ & $1,65 \%$ & Kurang Mampu & 3 & $11,11 \%$ \\
\hline \multicolumn{7}{|c|}{ Jumlah } & 27 & $100 \%$ \\
\hline
\end{tabular}

Sumber Data : Hasil diadopsi dari Nurgiantoro, 2001: 399 dengan beberapa perubahan

Berdasarkan data yang diperoleh dari tabel 1, menunjukkan bahwa hasil tes kemampuan peserta didik dalam memahami teks biografi dengan menggunakan metode the learning cell dalam tiga kali proses pembelajaran pada tes siklus I di kelas VIIID SMP Negeri 6 Wonomulyo. Jumlah peserta didik yang berada pada kategori mampu sebanyak 9 orang dengan persentase $33,33 \%$. Peserta didik yang berada pada 
kategori cukup mampu sebanyak 15 orang dengan persentase 55,55\%, peserta didik yang berada pada kategori kurang mampu sebanyak 3 orang dengan persentase $11,11 \%$, dan tidak terdapat peserta didik yang mencapai kategori sangat mampu.

Sehingga dapat disimpulkan bahwa bahwa hasil tes kemampuan memahami teks biografi peserta didik kelas VIIID SMP Negeri 6 Wonomulyo dengan menggunakan metode the learning cell berada pada kategori cukup mampu dengan persentase sebanyak 55,55\% dari jumlah peserta didik sebanyak 27 orang peserta didik yang berada di kelas VIIID SMP Negeri 6 Wonomulyo.

Jika nilai hasil kemampuan memahami teks biografi dikategorisasikan kedalam empat kategorisasi berdasarkan teknik kategorasi standar menurut (departemen Pendidikan Nasional) maka diperoleh data distribusi frekuensi seperti dalam tabel 2 sebagai berikut:

Tabel 2. Distribusi Frekuensi dan Presentase Hasil tes siklus II

\begin{tabular}{|c|c|c|c|c|c|}
\hline No & $\begin{array}{c}\text { Interval } \\
\text { kelas }\end{array}$ & Konversi & Kategori & Frekuensi & Persentase \\
\hline 1 & $90 \%-$ & $3,66 \%-$ & Sangat & 5 & $18,51 \%$ \\
2 & $100 \%$ & $4,00 \%$ & Mampu & 19 & $70,37 \%$ \\
3 & $72 \%-89 \%$ & $2,66 \%-$ & Mampu & 3 & $11,11 \%$ \\
4 & $57 \%-71 \%$ & $3,65 \%$ & Cukup & - & - \\
& $34 \%-56 \%$ & $1,66 \%-$ & Mampu & & \\
& \multicolumn{5}{|c|}{ Jumlah } \\
& $1,65 \%$ & Mampu & & $100 \%$ \\
\hline
\end{tabular}

Sumber Data : Hasil diadopsi dari Nurgiantoro, 2001: 399 dengan beberapa perubahan

Berdasarkan data yang diperoleh dari tabel 2, menunjukkan bahwa hasil tes kemampuan peserta didik dalam memahami teks biografi dengan menggunakan metode the learning cell dalam tiga kali proses pembelajaran pada tes siklus II di kelas VIIID SMP Negeri 6 Wonomulyo. Jumlah peserta didik yang berada pada kategori sangat mampu sebanyak 5 orang dengan persentase 18,51\%. Peserta didik yang berada pada kategori cukup mampu sebanyak 19 orang dengan 
persentase $70,37 \%$, peserta didik yang berada pada kategori kurang mampu sebanyak 3 orang dengan persentase 11,11\%, dan tidak terdapat peserta didik yang mencapai kategori sangat mampu.

Sehingga dapat disimpulkan bahwa bahwa hasil tes kemampuan memahami teks biografi peserta didik kelas VIIID SMP Negeri 6 Wonomulyo dengan menggunakan metode the learning cell berada pada kategori mampu dengan persentase sebanyak 70,37\% dari jumlah peserta didik sebanyak 27 orang peserta didik yang berada di kelas VIIID SMP Negeri 6 Wonomulyo

Penelitian pada siklus II ini dilaksanakan sebanyak 3 kali pertemuan, sama seperti siklus I. Dalam pelaksanaannya berlangsung tertib dan lancar. Setelah diberi tes, terlihat bahwa hasil belajar yang diperoleh peserta didik pada siklus II dengan nilai skor rata-rata 2,96 sedangkan skor rata-rata hasil belajar pada siklus I sebesar 2,54, hal ini membuktikan bahwa pada siklus II mengalami peningkatan dibandingkan dengan hasil yang diperoleh pada siklus I. Dilihat dari ketuntasan hasil belajar pada siklus II berjumlah 24 orang yang tuntas dengan persentase $85,71 \%$ secara klasikal sedangkan pada siklus I jumlah peserta didik yang tuntas sebanyak 18 orang dengan persentase $64,28 \%$. Sehingga pada siklus II hasil belajar peserta didik sudah mencapai nilai KKM sebesar 2,72 ketuntasan 85\%.

Dengan demikian, dapat disimpulkan bahwa pembelajaran metode the learning celldapat meningkatkan hasil belajar bahasa Indonesia peserta didik kelas VIII $_{D}$ SMP Negeri 6 Wonomulyo Kecamatan Buloa Kabupaten Polewali mandar.

\section{SIMPULAN}

Berdasarkan hasil penelitian dan pembahasan sebelumnya dapat disimpulkan bahwa penggunaan metode pembelajaran The Learning Cell dapat meningkatkan kemampuan memahami tes biografi peserta didik kelas VIIID SMP Negeri 6 Wonomulyo Kabupaten Polewali Mandar. Penggunaan metode TheLearning Cell memberika kontribusi dalam keberhasilan pencapaian indikatar dan nilai ketuntasan minimal (KKM)

Peningkatan kemampuan memahami teks biografi melalui penggunan metode The Learning Cell pada peserta didik kelas VIIID SMP 
Negeri 6 Wonomulyo Kabupaten Polewali Mandar berada pada kategori tinggi yaitu 2,8. Peningkatan tersebut juga dapat digambarkan berdasarkan data yang diperoleh bahwa dari 27 jumlah keseluruhan peserta didik, 24 atau $88 \%$ yang nilainya mencapai KKM yaitu 2,67, dan 3 atau 11\% peserta didik yang tidak mencapai nilai KKM yaitu 2,67. Disamping itu, dari hasil observasi selama proses pembelajaran berlangsusng di tiap siklusnya menunjukkan adanya perubahan sikap peserta didik kearah yang lebih positif, baik dari segi sikap belajar, keaktifan dalam membaca teks biografi, maupun kedisiplinan dalam mengerjakan tugas yang diberikan dalam pembelajaran memahami isi sebuah teks biografi melalui penggunaan metode The Learning Cell.

Hasil penelitian menggambarkan adanya hasil peningkatan hasil belajar bahasa Indonesia dan terjadinya perubahan sikap psitif peserta peserta didik maka diajukan beberapa saran sebagai berikut:

1. Para guru bahasa dan sastra dalam proses pembelajaran berperan sebagai fasilitator dan motivator, karena dengan begitu pembelajaran akan menjadi pengalaman yang sangat bermakna bagi peserta didik.

2. Metode pembelajaran The Learning Cell dapat dijadikan alternatif pilihan guru dalam proses pembelajaran di dalam kelas.

3. Penggunaan metode The Learning Cell sebagai upaya untuk mengoptimalkan hasil belajar peserta didik hendaknya disesuaikan materi pelajaran yang dibahas, mengingat penggunaan metode The learning Cell tersebut tentu cocok pada setiap materi pembelajaran.

4. Kepada peneliti selanjutnya diharapkan untuk mengembangkan penelitian ini agar peserta didik lebih mudah dalam memahami materi pelajaran yang diajakarkan sehingga dapat mengurangi kekurangan keberhasilan dalam proses belajar mengajar di sekolah. Penelitian ini hendaknya dapat dilanjutkan oleh peneliti lain yang berminat pada subyek serta obyek penelitian yang berbeda dengan memperhatiakan kekurangan -kekurangan yang ada. 


\section{DAFTAR PUSTAKA}

Alek dan Ahmad. 2010. Bahasa Indonesia Untuk Perguruan Tinggi. Jakarta. Kencana Pernada Media Group.

Kunandar. 2012. Langkah mudah penelitian tindakan kelas. Jakarta: RajaGrafindo Persada.

Rusman. 2009. Manajemen Kurikulum. Jakarta: RajaGrafindo Persadaiani.

Sugiarti, Wina. 2014. Penerapan Model Talking Stick Berorintasi Pendekatan Kooperatif dalam Pembelajaran Membaca Teks Biografi pada Siswa Kelas VII SMP. Bahtera Bahasa: Antologi Pendidikan Bahasa dan Sastra Indonesia.

Suprijono Agus. 2009. Cooperative Learning. Yogyakarta.Pustaka Belajar. Zabadi Fairul dan Sutejo. 2014. Bahasa Indonesia Wahana Pengetahuan. Jakarta: Grafindo Persada. 